\title{
Studies in Modern History
}

General Editor: J. C. D. Clark, Joyce and Elizabeth Hall Distinguished Professor of British History, University of Kansas

Titles include:

Bernard Cottret (editor)

BOLINGBROKE'S POLITICAL WRITINGS

The Conservative Enlightenment

Richard R. Follett

EVANGELICALISM, PENAL THEORY AND THE POLITICS OF CRIMINAL LAW

REFORM IN ENGLAND, 1808-30

Philip Hicks

NEOCLASSICAL HISTORY AND ENGLISH CULTURE

From Clarendon to Hume

Mark Keay

WILLIAM WORDSWORTH'S GOLDEN AGE THEORIES DURING THE

INDUSTRIAL REVOLUTION IN ENGLAND, 1750-1850

William M. Kuhn

DEMOCRATIC ROYALISM

The Transformation of the British Monarchy, 1861-1914

Kim Lawes

PATERNALISM AND POLITICS

The Revival of Paternalism in Early Nineteenth-Century Britain

Nancy D. LoPatin

POLITICAL UNIONS, POPULAR POLITICS AND THE GREAT REFORM ACT OF 1832

Marjorie Morgan

NATIONAL IDENTITIES AND TRAVEL IN VICTORIAN BRITAIN

James Muldoon

EMPIRE AND ORDER

The Concept of Empire, 800-1800

W. D. Rubinstein and Hilary Rubinstein

PHILOSEMITISM

Admiration and Support for Jews in the English-Speaking World, 1840-1939

Lisa Steffen

TREASON AND NATIONAL IDENTITY

Defining a British State, 1608-1820

Lynne Taylor

BETWEEN RESISTANCE AND COLLABORATION

Popular Protest in Northern France, 1940-45 


\section{Studies in Modern History}

Series Standing Order ISBN 0-333-79328-5

(outside North America only)

You can receive future titles in this series as they are published by placing a standing order. Please contact your bookseller or, in case of difficulty, write to us at the address below with your name and address, the title of the series and the ISBN quoted above.

Customer Services Department, Macmillan Distribution Ltd, Houndmills, Basingstoke, Hampshire RG21 6XS, England 


\section{William Wordsworth's}

Golden Age Theories during the Industrial Revolution in England, 1750-1850

Mark Keay 


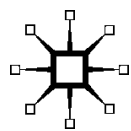

(c) Mark Keay 2001

Softcover reprint of the hardcover 1st edition 2001 978-0-333-79436-4

All rights reserved. No reproduction, copy or transmission of this publication may be made without written permission.

No paragraph of this publication may be reproduced, copied or transmitted save with written permission or in accordance with the provisions of the Copyright, Designs and Patents Act 1988, or under the terms of any licence permitting limited copying issued by the Copyright Licensing Agency, 90 Tottenham Court Road, London W1P OLP.

Any person who does any unauthorised act in relation to this publication may be liable to criminal prosecution and civil claims for damages.

The author has asserted his right to be identified as the author of this work in accordance with the Copyright, Designs and Patents Act 1988.

First published 2001 by

PALGRAVE

Houndmills, Basingstoke, Hampshire RG21 6XS and 175 Fifth Avenue, New York, N. Y. 10010

Companies and representatives throughout the world

PALGRAVE is the new global academic imprint of

St. Martin's Press LLC Scholarly and Reference Division and Palgrave Publishers Ltd (formerly Macmillan Press Ltd).

\section{ISBN 978-1-349-42018-6 \\ ISBN 978-1-4039-1956-4 (eBook) \\ DOI $10.1057 / 9781403919564$}

This book is printed on paper suitable for recycling and made from fully managed and sustained forest sources.

A catalogue record for this book is available from the British Library.

Library of Congress Cataloging-in-Publication Data Keay, Mark.

William Wordsworth's Golden Age theories during the Industrial Revolution in England, 1750-1850 / Mark Keay.

p. cm. - (Studies in modern history)

Includes bibliographical references and index.

ISBN 978-1-349-42018-6

1. Wordsworth, William, 1770-1850-Knowledge-History.

2. Wordsworth, William, 1770-1850-Political and social views.

3. Literature and society-England-History-19th century.

4. Literature and history-England-History - 19th century.

5. Pastoral poetry, English-History and criticism. 6. Industrial revolution-England-History. 7. Lake District (England)—In literature. 8. Golden age (Mythology) in literature. 9. Industrial revolution in literature. 10 Social values in literature. 11. Country life in literature. 12. Populism in literature. I. Title. II. Studies in modern history (Palgrave (Firm))

PR5892.H5 K43 2001

$821^{\prime} .7-\mathrm{dc} 21$

$\begin{array}{llllllllll}10 & 9 & 8 & 7 & 6 & 5 & 4 & 3 & 2 & 1\end{array}$

$\begin{array}{llllllllll}10 & 09 & 08 & 07 & 06 & 05 & 04 & 03 & 02 & 01\end{array}$ 
Children form the most conservative of human societies. Philippe Aries 
This page intentionally left blank 


\section{Contents}

Preface

viiii

Acknowledgements

$\mathrm{X}$

List of Abbreviations

Introduction

1 Old Lakeland: a Golden Age Ideal

2 Land Tenure: a Lake District Survey

3 Wordsworth and Cobbett: a Comparison

4 Wordsworth and Burke: a Contrast

5 Wordsworth: a Weberian Account

Appendix I Wordsworth's Use of the Words 'Peasant' and 'Peasantry' in his Poems, 1787-1850

Appendix II Wordsworth and the vices of an archaic tenurial law': a Rebuttal of Criticisms by V. G. Kiernan

Notes

Bibliography

Index 


\section{Preface}

This book should begin with a friendly warning. You will not find here another work of Romantic scholarship or even a cradle-till-grave biography of William Wordsworth. What you will find is a detailed case study of social and economic change and continuity during the Industrial Revolution in England. It does, of course, add something new to our understanding of English Romanticism, as well as supplying a thematic biography of William Wordsworth's life and work as a modern poet. It is, however, primarily a work of social and economic history and explanation. It starts moreover from a fresh perspective on Wordsworth's life and work which falls outside the tired (if not completely old-fashioned) frameworks of Marxist and post-structuralist accounts of the topic. In other words, it has a revisionist aim - to place Wordsworth within a living and historically credible world which does justice to his own perceptive remarks on Man, Nature and Society. In this respect it is based upon the social and economic research and - to a point - the political conclusions of revisionist historians of modern English society like J. C. D. Clark, William D. Rubinstein and A. J. Mayer who have each redefined our view of the old landed order between 1688 and 1914. Within this context of the 'old regime' in England, Wordworth is shown to represent, in certain respects, an antimodernist tradition in politics and literature that was opposed to the patchy class and industrial society and commercial values that were evident in the period 1750-1850. He was always 'a man speaking to men', but his views of social life and economic relations were arguably more like those of agrarian radicals such as William Cobbett and Feargus O'Connor than bona fide members of radical, whig or tory propaganda. They were based in fact upon an abiding sympathy with the 'common man', in general, and a Golden Age ideal of social life and moral relations, in particular, which arose from his experience of a vanishing way of life in Old Lakeland in the years 1770-89. Above all, this book reveals that Wordsworth's ill-defined status in the old landed order was the social cause of his need for, and satisfaction with, the populist perspective of the old-fashioned farmers, labourers and artisans of the remote north. Sharing the values and ideals of the social class beneath him, the 'well-to-do' Wordsworth sought to reform the effete culture and feelings of those around and above him. His most radical poetry therefore was, socially speaking, complementary to, but not quite dependent upon, the democratic aims and political objectives of the French Revolution. Furthermore, his own revolution in art and culture was, 
emotionally speaking, based upon backward looking ideas and pre-modern forms of thought and feeling, which were found in a particular historical context, namely the Lake District community. Hence my original caveat to would-be reviewers and lay readers. Read this book as a contribution to social and economic history or you will, probably, miss the point.

MARK KEAY 


\section{Acknowledgements}

I have a number of formal acknowledgements to make here. First, I gratefully acknowledge the receipt of a Deakin University Postgraduate Research Award, from the Faculty of Arts, which has enabled me to study full-time for almost three years.

In the course of my primary research I have been helped by a number of private and public libraries both in Australia and England. In particular, I would like to thank the staffs of the following libraries: the Inter-library Loans Office at Deakin University, Geelong; the Baillieu Library at the University of Melbourne; the Borchardt Library at La Trobe University, Bundoora; the Rare Books Collection at the State Library of Victoria; the Institute of Historical Research, London; the Wordsworth Room at the University of Lancaster; the Kendal Library (Stricklandgate), Kendal; and the Kendal Records Office. Above all, I would like to thank Professor Robert Woof of Dove Cottage Library, in Grasmere, for permission to use material from the Trust's collection and for his hospitable reception of a young scholar 'from down under'. In the same vein I would like to thank his chief assistant, Dr Jeff Cowton, for his friendly help on a number of occasions.

My next acknowledgements are, perhaps, the most important. I wish to thank my assistant supervisor, Dr Roy Hay, for his earnest efforts to keep my 'conservative' theory upon the straight and narrow path of academic fairness towards my 'left-wing' opponents. Of course, I alone am responsible for any problem which may yet remain on this score. My debt to my principal supervisor, Professor Bill Rubinstein, is almost too great to admit in a brief sentence: I will simply say that he is a first rate teacher, mentor and historian.

Likewise Professor Jonathan Clark has been a superb representative and editor for Palgrave. He has encouraged my labours at all stages of publication and has now seen the work to its final destination in print. I thank him most sincerely for the time and effort he has bestowed upon my book.

I have also to thank my brother, Kevin Keay, for making the mysteries of Microsoft Word less esoteric to me.

Above all, I must dedicate this book to my wife, Veronica, and to our children, Renwein and Stephanie, who have travelled to far away places in search of history and truth. I hope their love and devotion have not been wasted. 


\section{List of Abbreviations}

$\begin{array}{ll}\text { AHEW } & \text { Agrarian History of England and Wales } \\ \text { AHR } & \text { Agricultural History Review } \\ \text { BPP } & \text { British Parliamentary Papers } \\ \text { DNB } & \text { Dictionary of National Biography } \\ \text { DNBMP } & \text { Dictionary of National Biography: Missing Persons } \\ \text { ECHR } & \text { Economic History Review } \\ \text { ECS } & \text { Eighteenth Century Studies } \\ \text { EHR } & \text { English Historical Review } \\ \text { HT } & \text { History and Theory } \\ \text { HW } & \text { History Workshop } \\ \text { IRSH } & \text { International Review of Social History } \\ \text { JBS } & \text { Journal of British Studies } \\ \text { JMH } & \text { Journal of Modern History } \\ \text { JRSS } & \text { Journal of the Royal Statistical Society } \\ \text { MEB } & \text { Boase's Modern English Biography } \\ \text { MP } & \text { Modern Philology } \\ \text { NH } & \text { Northern History } \\ \text { PP } & \text { Past \& Present } \\ \text { PR } & \text { Cobbett's Weekly Political Register } \\ \text { SH } & \text { Social History } \\ \text { SIP } & \text { Studies In Philology } \\ \text { CW2 } & \text { Transactions of the Cumberland and Westmorland } \\ \text { TIBG } & \text { Antiquarian and Archaeological Society, 2nd Series } \\ \text { TRHS } & \text { Transactions of the Institute of British Geographers } \\ \text { VCH Cumb. } & \text { Transactions of the Royal Historical Society } \\ \text { comp. } & \text { The Victoria County History of Cumberland } \\ \text { pub. } & \text { Date of composition. } \\ & \text { Date of publication. }\end{array}$

